Background The mechanism by which methotrexate (MTX), a well known antifolate inhibits inflammation is still unknown. The inflammation in rheumatoid arthritis is mediated by proinflammatory cytokines such as TNF $\alpha$ and IFN $\gamma$.

Objectives To assess whether cytokine production in blood of RA patients is inhibited after taking MTX.

Methods Blood was obtained from 25 RA patients at $\mathrm{T}=0 \mathrm{~h}$ and $\mathrm{T}=2 \mathrm{~h}$ after taking MTX (10 $\mathrm{mg}$ or) for the first time. Heparinized Whole Blood Cultures (WBC; dilution 1/4) using anti-CD3 and anti-CD28 as stimulus were performed, with and without addition of folinic acid $(40 \mathrm{~g} / \mathrm{ml})$ to the culture. Because MTX has been reported to induce IL-10 production all experiments were also carried out with and without excess neutralising $\mathrm{mAb}$ to IL-10. After incubation for $72 \mathrm{~h}$ supernatants were measured by ELISA.

Results IFN $\gamma$ production by WBC of 25 RA patients before (T $=0 \mathrm{~h})$ and after $(\mathrm{T}=2 \mathrm{~h}) \mathrm{MTX}$.

\begin{tabular}{|c|c|c|c|c|}
\hline & $\begin{array}{l}\text { IFN } \gamma^{*} n g / \\
\mathrm{ml}\end{array}$ & $\begin{array}{l}\text { IFN } \gamma \text {, FA } \\
\text { added }\end{array}$ & $\begin{array}{l}\text { IFN } \gamma \text {, anti IL } 10 \\
\text { added }\end{array}$ & $\begin{array}{l}\text { IFN } \gamma, F A \text { and anti IL } \\
10\end{array}$ \\
\hline $\begin{array}{l}T=0 \\
h\end{array}$ & $53(12)$ & $39(10)^{2}$ & $94(17)$ & $78(16)$ \\
\hline $\begin{array}{l}T=2 \\
h\end{array}$ & $19(5)^{1}$ & $48(12)^{3}$ & $27(6)^{4}$ & $93(17)$ \\
\hline
\end{tabular}

Conclusion MTX inhibits ex vivo IFN $\gamma$ production in RA patients by a folate dependent mechanism. MTX does not act via induction of IL-10. Similar results were found for TNF $\alpha$ and GM-CSF. IL-8 production is not affected by MTX.

\section{THU0045 LOCAL PRODUCTION AND MODULATION OF COMPLEMENT PROTEINS IN RHEUMATOID ARTHRITIS SYNOVIUM}

${ }^{1} \mathrm{U}$ Müller-Ladner, ${ }^{1} \mathrm{I}$ Tarner, ${ }^{2} \mathrm{~S}$ Barnum, ${ }^{2} \mathrm{~J}$ Echols, ${ }^{1} \mathrm{E}$ Neumann, ${ }^{1} \mathrm{M}$ Fleck, ${ }^{1} \mathrm{M}$ Judex, ${ }^{1} \mathrm{~F}$ Kullmann, ${ }^{2} \mathrm{~J}$ Mountz, ${ }^{1} \mathrm{~J}$ Schölmerich, ${ }^{3} \mathrm{~S}$ Gay. ${ }^{1}$ Department Internal Medicine I, University Hospital, Regensburg, Germany; ${ }^{2}$ Departments Microbiology and Rheumatology, UA, Birmingham, AL, USA; ${ }^{3}$ trt. Exp. Rheum., USZ, Zürich, Switzerland

10.1136/annrheumdis-2001.842

\section{Background}

Objectives Rheumatoid arthritis (RA) is a severe chronic disease characterised by inflammation of synovial tissue, which causes pain and dysfunction of joints and leads to their destruction. In RA, complement has been implicated in inflammation and joint destruction based on studies showing reduced levels of native complement components and increased levels of complement metabolites in plasma, synovial fluid and synovial tissue of RA patients. However, there is limited information on local production and activation of key factors of the complement cascade in RA synovium and their potential modulation by novel anti-cytokine therapies.

Methods Using in situ hybridization, immunohistochemistry and Western blot techniques, the presence of complement proteins C3, factor B and Sc5b-9 and of the complement receptors C3aR and C5aR were evaluated in RA and osteoarthritic (OA) synovium. In addition, C3 and factor B levels in synovial fluid were determined by ELISA. Functional assessment was performed by examination of the effects of adenovirus-based sTNF-R p55 gene transfer into RA synovial fibroblasts in the SCID mouse model.

Results Complement proteins C3 and factor B were synthesised mainly around terminal vasculature in all (6/6) RA synovial specimens whereas complement receptors $\mathrm{C} 3 \mathrm{aR}$ and $\mathrm{C} 5 \mathrm{aR}$ were expressed in adjacent inflammatory infiltrates. In contrast, only limited local production of these factors could be observed in OA. Different activation of the complement cascade was illustrated by more intensive degradation of factor B in RA as compared to OA synovial fluid (mean: 28 vs. $48 \mu \mathrm{g} / \mathrm{ml}$ ). Overexpression of sTNFRp55 revealed upregulation of C5 but not C3 receptor expression in the transduced RA synovial fibroblasts indicating differential effects of anti-cytokine therapies on complement factors in RA synovium.

Conclusion We conclude that local complement production and activation may play an important role in RA synovium. Moreover, modulation or inhibition of local complement production, e.g. by biologic agents and anti-C5 antibodies, which are currently investigated in clinical trials, could be an attractive therapeutic approach for RA.

\section{THU0046 SERUM SOLUBLE SELECTINS LEVELS IN PATIENTS WITH RHEUMATOID ARTHRITIS AND SYSTEMIC SCLEROSIS}

A Ates, G Kinikli, M Turgay, M Duman. Clinical Immunology and Rheumatology, Ankara University Medical School, Ankara, Turkey

\subsection{6/annrheumdis-2001.843}

Background Soluble forms of adhesion molecules may be found in the circulation, and increased levels of selectins have been reported in some connective tissue diseases. It was suggested that the measurement of levels of circulating soluble selectins is useful as an indicator of inflammatory disease.

Objectives To determine serum levels of soluble (s) E-, L-, and Pselectin in patients with rheumatoid arthritis (RA) and systemic sclerosis (SSc), and to determine whether levels of these molecules correlate with measures of disease activity and pulmonary involvement.

Methods Serum levels of sE-, L-, and P-selectin were determined by sandwich ELISA in 34 patients with RA, 30 patients with SSc and 15 healthy subjects. The patients with RA were classified according to disease activity, functional status, Larsen score reflecting anatomical joint damage, and the presence of pulmonary involvement. The presence of pulmonary fibrosis and DLCO were determined in patients with SSc.

Results The mean soluble selectin levels are shown in Table 1. sE- and sL-selectin levels were significantly higher in patients with active RA compared to inactive patients (respectively $\mathrm{p}<$ 0.05 and $\mathrm{p}<0.05$ ). Although sP-selectin level was higher in active RA patients than those in inactive patients, the difference did not reach statistically significant $(p=0.06)$. Significant correlations were found between sL-selectin and CRP $(p<0.05)$, and white blood cell count $(\mathrm{p}<0.01)$ and between sP-selectin and CRP $(\mathrm{p}<0.01)$, and erythrocyte sedimentation rate $(\mathrm{p}<$ $0.01)$. There were no correlations between selectin levels and Larsen score. sE-selectin level was increased in RA patients with advanced functional impairment $(56.0 \pm 39.8$ in stage III-IV vs. $32.7 \pm 13.6 \mathrm{ng} / \mathrm{ml}$ in stage I-II, $\mathrm{p}<0.05)$. The presence of pulmonary involvement in patients with RA was not correlated with soluble selectin levels. sE-selectin levels was significantly higher 